\title{
GELADEIROTECA: UMA AÇÃO DE LEITORES, PELA DEMOCRATIZAÇÃO DA LEITURA
}

\section{GELADEIROTECA: AN ACTION OF READERS FOR THE DEMOCRATIZING READING}

\section{Eloiza Marinho dos Santos ${ }^{1}$ Maria José de Pinho ${ }^{2}$}

\begin{abstract}
Resumo: O artigo aborda leitura, formação de leitores e democratização da leitura. Tem como objetivo refletir sobre a necessária democratização do acesso à leitura, a partir da experiência do Projeto Geladeiroteca, à luz de fundamentos teóricos construídos em diálogo com os autores: Castrillón, Freire, Petit, Rouxel, Soares, Zilberman, entre outros. Relata uma iniciativa de estudantes da UFMA, campus de Imperatriz-MA, que buscam uma forma criativa de incentivar a leitura na universidade. $O$ projeto nasce numa disciplina ministrada no curso de Ciências Contábeis, com orientação da Prof a Celnia Teresinha Bastos, e ganha adesão de estudantes de outros cursos, como Matheus, do curso de Pedagogia. A ideia era criar uma estratégia de compartilhar livros e incentivar a leitura no ambiente acadêmico. Uma geladeira usada, encontrada por um aluno de Contábeis, transforma-se em cenário: a Geladeiroteca. Os estudantes tornam-se protagonistas. Foram utilizadas entrevistas semiestruturadas para colher informações junto à coordenadora do projeto original, professora Celnia, Matheus que se tornou divulgador do projeto e três estudantes que utilizam os livros da Geladeiroteca: uma estudante de Pedagogia e dois estudantes de LCH. Enfim, não basta saber ler, no sentido da ação formal de decodificar a escrita, é preciso tornar-se leitor, como alguém capaz de dialogar com o texto, com o mundo, com a realidade para, a partir dela e com ela, buscar alternativas de transformação.
\end{abstract}

Palavras chave: leitura; formação de leitores; democratização da leitura; geladeiroteca

\begin{abstract}
The article is about reading, readers' training and reading democratization. The purpose is to reflect upon the necessary democratization of the access to reading, taking into account the experience of the Project Refrigerator Library, under theoretical bases gathered from dialogues with the authors: Castrillón, Freire, Petit, Rouxel, Soares, Zilberman, among others. It reports an initiative of students from UFMA, campus of Imperatriz-MA, who are looking for a creative way to encourage reading at the university. The project came into life out of a subject matter taught in the Accounting Science Course, with the guidance of Prof.

\footnotetext{
${ }^{1}$ Doutoranda do Programa de Pós-Graduação em Letras: Ensino de Línguas e Literatura - PPGL, da UFT, câmpus de Araguaína.

${ }_{2}^{2}$ Professora da Universidade Federal do Tocantins.
} 
Celnia Teresinha Bastos, and gets adhesion from students of other courses, such as Matheus, who is a Pedagogy Course student. The idea is to create a strategy to share books and encourage reading in the academic environment. A used refrigerator, found by an Accounting Course student, becomes the scenario: the refrigerator library. Students become protagonists. Semi-structured interviews were used to gather information from the original project coordinator, Professor Celnia, Matheus who became the project's promoter and three students who uses the refrigerator library books: one Pedagogy student and two LCH students. Finally, it is not enough to know how to read, regarding the formal action of decoding the writing, it is necessary to become a reader, as someone capable of dialoguing with the text, with the world, with reality, from it and with it, seeking transformation alternatives.

Keywords: reading; readers' training; democratization of reading; refrigerator library.

\section{Introdução}

A ideia do tema começou a ser gestada durante as aulas da disciplina Mulheres formadoras de leitores: crítica, autoria e ensino, ministrada pela professora Dra ${ }^{\mathrm{a}}$. Ana Crélia Dias, no Programa de Pós-Graduação em Letras: Ensino de Línguas e Literatura - PPGL, da Universidade Federal do Tocantins - UFT, câmpus de Araguaína.

Em um dos retornos à Imperatriz-MA, procurei o Centro Acadêmico de Pedagogia Paulo Freire (CAPed), da Universidade Federal do Maranhão (UFMA), campus de Imperatriz-MA para que me ajudasse a disponibilizar para os estudantes uns livros que tinha "desapegado" da minha biblioteca pessoal.

Valdean, presidente do CAPed, acolheu prontamente todo o material e, com os colegas, foram logo separando por área. Foi, então, que me falaram da "geladeira literária". Naquele momento achei interessante, mas não me detive muito sobre essa iniciativa; estava ocupada demais, às vésperas de viajar para a última etapa da disciplina da profa. Ana Crélia Dias.

Quando finalizamos os encontros da disciplina pude focar melhor na atividade final que era a elaboração de um artigo científico. Comecei, então, a pensar mais detidamente sobre formação de leitores e sobre democratização da leitura. E no contato com o primeiro período do curso de Pedagogia, com mais alguns livros para doar, uma aluna me falou da geladeira; contou-me que ela mesma já havia pegado vários livros, lido e devolvido. Foi meu gatilho!

Passei a pensar sobre esse projeto de incentivo à leitura que parte dos próprios estudantes. Quem teve a ideia do projeto? Por quê? Como funciona? Qual a finalidade, 
segundo os proponentes do projeto? Quem são os usuários da tal geladeira e o que pensam sobre essa iniciativa?

São muitas indagações que pretendemos responder neste artigo, mas o principal objetivo é refletir sobre a necessária democratização do acesso à leitura, a partir da experiência da Geladeiroteca, à luz de fundamentos teóricos construídos em diálogo com os autores: Castrillón, Freire, Petit, Rouxel, Soares, Zilberman, entre outros.

Cabe esclarecer que conheci o projeto como "Geladeira Literária", uma ação fomentada por um estudante do curso de Pedagogia. Depois descobri que a ideia da geladeira nasceu no curso de Ciências Contábeis com o nome de "Geladeiroteca". Sendo assim, procurarei utilizar a nomenclatura de origem, referindo-me à geladeira literária somente quando for indispensável ao relato.

Então, o artigo traz uma reflexão sobre leitores. Relata uma iniciativa de estudantes do ensino superior, notadamente da UFMA, campus de Imperatriz-MA, que criam uma estratégia de compartilhar livros e incentivar a leitura no ambiente acadêmico. $\mathrm{O}$ projeto tem sua origem numa disciplina ministrada no curso de Ciências Contábeis, pela Prof ${ }^{a}$ Celnia Teresinha Bastos, e ganha adesão de estudantes de outros cursos, como Pedagogia e Licenciatura em Ciências Humanas (LCH). Uma geladeira usada, encontrada por um aluno de Contábeis, transforma-se em cenário: a "Geladeiroteca". Os estudantes tornam-se protagonistas. A autora do artigo faz-se narradora desse enredo que defende a democratização do acesso às práticas variadas de leitura.

Para contar essa história da Geladeiroteca, procurei ouvir, por meio de entrevistas semiestruturadas, a professora Celnia, fomentadora do projeto original no curso de Contábeis; o Matheus Ian, aluno do curso de Pedagogia, que aderiu ao projeto e, por iniciativa própria divulgou a geladeira e fez algumas doações de seu próprio acervo; três estudantes que fazem uso da Geladeiroteca: uma é aluna do curso de Pedagogia (Maria Carolina) e os outros dois são estudantes de LCH (Vitor Emanuel e Sara Lorrana).

O artigo está organizado da seguinte forma: após esta introdução, começo com uma reflexão sobre leitura e formação de leitores, buscando estabelecer um diálogo com o que dizem os autores acerca da democratização da leitura, depois falo sobre a experiência da Geladeiroteca da UFMA/Imperatriz, a iniciativa de sua criação, explorando o que é o projeto, sua origem e finalidades, analiso seus impactos e, finalmente, teço algumas considerações encerrando o artigo. 


\section{Leitura e formação de leitores: breves reflexões sobre democratização da leitura}

Inicio esta reflexão com a constatação, até óbvia, de que a leitura é uma ação eminentemente humana, uma experiência singular vivenciada pelo leitor na relação com o texto, especialmente o literário. Para Rouxel (2012, p. 278), a "leitura se torna uma experiência humana de forte envolvimento simbólico", trazendo com isso, a subjetividade do leitor como elemento indispensável nas práticas de leitura.

Na história humana, percebe-se que a leitura foi (e muitas vezes ainda é) utilizada como instrumento de poder, quando instituições como a Igreja e o Estado tentam manter o controle sobre o que é permitido ou não ler. E, ainda, quando a leitura é colocada a serviço do poder econômico que determina as regras sobre quem pode ler e o quê se deve ler, de modo a atender os interesses do mercado, elegendo algumas leituras como necessárias à formação do trabalhador (quando lhes possibilitam o acesso) e aquelas apropriadas à formação da elite, cujo acesso é sempre garantido.

Assim, podemos observar que em cada época a leitura vai tendo uma conotação diferente, sobretudo quando se trata da leitura praticada em ambiente pedagógico, como na escola, lugar autorizado, por excelência, a ensinar ler e escrever. Silva (2008, p. 47), faz menção à leitura sob diferentes abordagens pedagógicas. Na pedagogia tradicional, a leitura é “concebida como imitação dos clássicos para efeito de memorização e verniz" (idem); na pedagogia moderna, sob influência do positivismo, à sombra do cientificismo, "Ler, para o aluno, é delinear um problema, estabelecer hipóteses e partir para a verificação destas no corpo das obras" (idem); na pedagogia tecnicista, o currículo escolar é visto como "' "pacote' para consumo rápido", cabendo ao aluno "ler o suficiente para se encaixar no mercado de trabalho" (idem).

Tais concepções nos remetem ao entendimento de que saber ler, necessariamente não é tornar-se leitor. Nessa perspectiva, Versiani e Martins (2004, p. 09), citando Soares (1988), declaram que "ao povo permite-se que aprenda a ler, não se lhe permite que se torne leitor". Pode-se, então, afirmar, que entre saber ler e tornar-se leitor, há um caminho formativo a ser percorrido e que a formação do leitor é uma decisão politica, visto que tem a ver com concepções de ser humano, de mundo e de sociedade, se deseja formar. Trata-se de formar um cidadão que consegue decodificar a língua escrita que, portanto, lê um texto, ou um cidadão 
que além de decodificar a escrita, compreende o texto e faz uso dessa ferramenta em suas práticas cotidianas.

Nesta seção procuramos refletir sobre leitura como direito essencial de cada cidadão, numa justa defesa da democratização da leitura. Inicialmente procuramos esclarecer as concepções de leitura e formação de leitor que defendemos. Em seguida abordamos a democratização, a partir do acesso equitativo à leitura.

\subsection{Leitura e formação de leitores: algumas concepções}

Nossa proposição é pensar a leitura numa contraposição à perspectiva restrita e dominadora de leitura como reprodução de textos clássicos, memorização, num viés positivista, ou ainda tecnicista, em que o domínio da leitura é utilizado para inserção no mundo do trabalho. Aqui, estamos procurando construir uma reflexão sobre a leitura como prática social e como direito essencial de toda pessoa.

Por ser assim, defendemos a leitura compreendida como algo mais que saber ler, isto é, que está para além da aquisição das ferramentas para decodificação de sinais gráficos como no processo de alfabetização; mas leitura entendida como uma experiência pessoal do leitor com o texto. Ou como diz Zilberman (2008, p. 22), "como atividade propiciadora de uma experiência única com o texto literário".

Uma vez que a leitura acontece na relação que se estabelece entre leitor e texto, ela também se alonga para a realidade em que o leitor se inscreve. Diz Rouxel (2012, p. 281) que "É pelo vínculo estabelecido entre o universo da obra e o universo do leitor que o ato de ler ganha sentido e se inscreve na vida do sujeito". Trata-se do envolvimento do leitor com o texto lido.

Para Freire (1989) a leitura da escrita, numa perspectiva crítica, não pode desconsiderar a leitura do mundo, isto é, o conhecimento da realidade. O autor fala do processo que envolve

[...] uma compreensão crítica do ato de ler, que não se esgota na decodificação pura da palavra escrita ou da linguagem escrita, mas que se antecipa e se alonga na inteligência do mundo. A leitura do mundo precede a leitura da palavra, daí que a posterior leitura desta não possa prescindir da continuidade da leitura daquele (FREIRE, 1989, p. 9).

Então não basta ler, no sentido da ação formal de juntar palavras, frases, como que decifrando a escrita, é preciso tornar-se leitor, como alguém capaz de dialogar com o texto, 
com o mundo, com a realidade para, a partir dela e com ela, buscar alternativas de transformação.

Não queremos, com isso, atribuir à leitura a complexa tarefa de transformação social, política ou econômica, como se só bastasse a um povo ter adquirido tal habilidade para mudar sua realidade. Porém, compreendemos que uma sociedade que não lê, sobretudo com autonomia, com reflexão e criticidade, dificilmente vai conseguir enxergar sua realidade e o que precisa ser transformado para melhorar as condições de vida coletiva. Poderíamos até dizer que, nesse sentido, leitura (como cultura) e desenvolvimento parecem andar juntos.

Castrillón (2011, p. 18) afirma que "se houvesse mais desenvolvimento, haveria mais leitura, ou, melhor dizendo, mais consumo de livros; assim como mais desenvolvimento, mais consumo de bens culturais e não culturais". Nessa perspectiva, desenvolvimento econômico, político, social, cultural, caminham lado a lado. Na negligência de um, as consequências são refletidas nos outros aspectos.

Desenvolvimento aqui se relaciona também com justiça social; desenvolvimento que gera condições de vida digna para todos, que garante o direito à participação de todos no acesso aos bens e direitos produzidos pela sociedade. E a leitura é um desses direitos que todos precisam ter assegurado.

Para a autora (idem), “o problema da leitura só pode ser 'encarado e resolvido' por meio de mudanças voltadas a uma mais justa e igualitária distribuição de riqueza". Afinal, uma sociedade, cujo acesso aos bens materiais é desigual, é restrito a uma pequena parcela de cidadãos privilegiados, se sustenta também, nessa condição de diferenças, pelo cerceamento cultural a uma parte desprivilegiada da sociedade, e pelo controle de acesso a tudo o que pode produzir consciência, visão crítica da realidade de excluídos dos bens materiais e não materiais.

Tornar-se leitor pode ser uma importante abertura para a conquista de autonomia do pensamento, da consciência crítica, da própria condição de sujeito de direito, de cidadão, dificultando o poder de dominação, de controle.

Do ponto de vista escolar, a leitura esteve muito ligada às aulas de Língua Portuguesa e Literatura, sendo estas disciplinas responsabilizadas, historicamente, por incentivar a leitura, assim como a escrita, dos alunos.

Desse modo, para falar de leitura trazemos algumas reflexões acerca da literatura. É importante observar que houve uma mudança significativa sobre o que se entendia ser a 
competência da literatura e como ela se apresenta hoje. Se a literatura, no passado, tinha a função de garantir ao estudante, sobretudo àqueles representantes da esfera privilegiada da sociedade, o acesso a um patrimônio cultural autorizado, clássico, nobre, em tempos atuais, ela se preocupa com a formação do leitor.

Se ao leitor do passado cabia um papel passivo, previsível, agora se espera formar um leitor capaz de fazer a sua imersão pessoal no universo literário, estabelecendo diálogo com o texto e com a realidade; nesse sentido, a experiência vivenciada pelo leitor de hoje não poderá ser previsível, controlada. Assim, segundo Zilberman (2008, p. 22), "Compete hoje ao ensino da literatura não mais a transmissão de um patrimônio já constituído e consagrado, mas a responsabilidade pela formação do leitor”. E para realizar tal competência, segundo a autora, é necessária uma concepção de leitura que avança do entendimento de "leitura não como o resultado satisfatório do processo de alfabetização e decodificação de matéria escrita, mas como atividade propiciadora de uma experiência única com o texto literário. A literatura se associa então à leitura, do que advém a validade dessa" (idem).

Quando se fala em formação do leitor, há que se considerar que este não se torna leitor apenas por ter sido inserido no currículo escolar o ensino de literatura, desconsiderando, muitas vezes as experiências de leitura vivenciadas pelo estudante em outros lugares e momentos. Sobre essa questão, Zilberman (2008, p. 52) alerta:

[...] formar não é moldar, dar consistência ao que não existe, ignorando a história anterior dos sujeitos participantes do processo pedagógico ou das instituições a que se integram.

Os atuais métodos de alfabetização sublinham, [...] que o alfabetizando já traz uma 'leitura de mundo' quando começa a frequentar a escola, afirmação que se aplica sem constrangimento a outras áreas do conhecimento. (ZILBERMAN, 2008, p. 52)

Defendemos, aqui, uma concepção de formação que leva em consideração os conhecimentos e as experiências (no caso, de leitura) vivenciadas pelos sujeitos em formação, sejam aquelas promovidas em instituição oficial ou não. E ainda, que entenda estes sujeitos como protagonistas no próprio processo (auto)formativo. Sendo assim, em relação ao sujeito leitor, podemos dizer com Zilberman que

[...] todo estudante é um leitor, antes de ser iniciado ao ensino de literatura; "formálo", portanto, significa antes de tudo: dar condições para ele descobrir que sua convivência com o texto e a escrita antecede sua relação com uma instituição reconhecida e legitimada pela sociedade a que chamamos de literatura; está presente em boa parte dos momentos de sua vida. (ZILBERMAN, 2008, p. 52) 
Descobrir que o contato com a leitura antecede as exigências acadêmicas, escolares, e se estende para além do universo pedagógico, é fundamental para o processo formativo do leitor; tanto para a escola quanto para o próprio leitor, esse (re)conhecimento de si, enquanto sujeito leitor que (inter)age com os textos para além da escola, enquanto instituição formadora, é condição necessária para ampliar a concepção de formação de leitores. É importante reconhecer-se como leitor, capaz de compreender seus limites, mas também de ter autonomia nas suas escolhas literárias.

Cabe à escola buscar, no diálogo, estratégias que favoreçam o conhecimento das experiências de leitura de seus alunos. Para tanto, Zilberman sugere que "O professor não pode conhecer seus alunos se não promover a interação da experiência de leitura já adquirida entre os leitores com que trabalha" (2008, p. 53).

Silva (2008, p. 55) tece algumas críticas ao que chama de "constrangimentos didáticos" provocados pela atuação do professor que busca diversos mecanismos para motivar o aluno a ler, tornando suas aulas ricas em "artifícios, manobras, incentivos e/ou controles a fim de operacionalizar a leitura escolar" (idem), distanciando-se, assim, dos objetivos da leitura na escola.

A função do professor seria de mediador de leitura; planejar diferentes situações que garantam o acesso dos alunos às mais diversas experiências de leitura. Diz Silva (2008, p. 57) que o professor "Não teria que motivar, mas apenas imaginar formas de causar a aproximação entre as crianças e as obras literárias. Dispor e expor, deixando que as obras, ao sabor das diferentes leituras das crianças, desabrochassem conhecimento e beleza". Mas para tanto, o professor precisaria ser também um leitor persistente e a escola deveria estar equipada com ambiente e livros em quantidade e diversidade suficientes para assegurar tais vivências.

\subsection{Democratização da leitura}

Para falar da democratização da leitura, é importante deixar claro a que me refiro quando falo em democracia. Diz Freire (1986, p. 80) que a democracia, "antes de ser forma política, é forma de vida". E nessa concepção incluo categorias como a participação, o diálogo, a criticidade, justiça, a consciência do coletivo, do exercício da cidadania como direito de todos e construção coletiva. A estas, acrescento o que diz Soares (2004, p. 18) que pensa "democracia como uma repartição, um partilhamento justo, não discriminativo de bens 
materiais e simbólicos". Mas sobre qual democracia estamos falando, uma vez que há uma diversidade de qualificativos para a democracia: política, econômica, social, cultural? Nesse caso, procuraremos tratar da democracia cultural, tendo como objeto a leitura.

Aqui, nos remetemos à leitura não obrigatória; aquela leitura que o sujeito escolhe fazer, utilizando seus próprios critérios ou objetivos; podendo ser uma leitura de cunho "pragmático - ler para se instruir, ler para se informar, ou 'gratuito' - ler por prazer, ler como lazer" (SOARES, 2004, p. 19). No entanto, sabemos que, na realidade brasileira, essa escolha não é tão simples assim, pelo fato de que boa parte da população não tem condições de acesso à literatura, aos livros.

Há, em nossa sociedade, uma desigualdade perceptível na distribuição não só de bens materiais, como também os não materiais, como a cultura, por exemplo.

Tratando-se da leitura, como bem simbólico, direito do cidadão, constata-se que muitos são os obstáculos enfrentados pelas camadas populares para terem acesso mínimo. Soares (2004, p. 21) aponta algumas barreiras que impedem o direito à leitura, como o fracasso na alfabetização e no letramento, raras e precárias bibliotecas públicas e escolares.

De acordo com o Sistema Nacional de Bibliotecas Públicas (SNBP) que realizou um levantamento de dados em 2015, no Brasil havia 6.057 bibliotecas públicas (municipais, distritais, estaduais e federais), nos 26 estados e no Distrito Federal ${ }^{3}$.

E segundo o $\mathrm{IBGE}^{4}$, com dados de referência em $1^{\circ}$ de julho de 2018, havia 5.570 municípios brasileiros e uma estimativa de 208,5 milhões de habitantes no Brasil. Portanto, são mais de 30 mil pessoas por biblioteca pública.

Em relação à bibliotecas escolares ou salas de leitura nas escolas, a situação também é muito séria. No site da Câmara dos Deputados consta a informação, datada de 06/12/2018, que, de acordo com o INEP, "55\% das escolas brasileiras não têm biblioteca ou sala de leitura"5. Diz, ainda, o texto:

Lei de 2010 determina que até maio de 2020 todas as escolas brasileiras tenham biblioteca, e a Comissão de Educação da Câmara acompanha o cumprimento da lei.

\footnotetext{
${ }^{3}$ Informação disponível em: <http://snbp.cultura.gov.br/bibliotecaspublicas/> Acesso em 07/08/2019.

${ }^{4}$ Notícia postada em 29/08/2018, disponível em: <https://agenciadenoticias.ibge.gov.br/agencia-sala-deimprensa/2013-agencia-de-noticias/releases/22374-ibge-divulga-as-estimativas-de-populacao-dos-municipiospara-2018> Acesso em 07/08/2019.

${ }^{5}$ Disponível em: <https://www2.camara.leg.br/camaranoticias/noticias/EDUCACAO-E-CULTURA/566523DADOS-DO-INEP-MOSTRAM-QUE-55-DAS-ESCOLAS-BRASILEIRAS-NAO-TEM-BIBLIOTECA-OUSALA-DE-LEITURA.html> Acesso em 07/08/2019.
} 
Das 180 mil escolas brasileiras, 98 mil ou 55\% não têm biblioteca escolar ou sala de leitura. ${ }^{6}$

O fato de haver uma legislação que assegura o direito ao acesso mínimo a um ambiente com livros, não significa que haja a democratização das condições essenciais para garantir a leitura. A ausência ou a escassez de espaços, livros e outros equipamentos, a falta de formação de mediadores de leitura são alguns dos obstáculos ao processo de democratização da leitura.

Soares (2004, p. 21) chama atenção também para a precariedade de muitas dessas bibliotecas que se tem visto no Brasil,

$$
\begin{aligned}
& \text { [...] sabe-se bem o pequeno e quase sempre desatualizado acervo que a maioria tem, } \\
& \text { sabe-se bem que funcionam mais como depósito de livros que como verdadeiras } \\
& \text { bibliotecas, centros de informação, de formação de leitores, sabe-se bem as enormes } \\
& \text { dificuldades com que lutam para sobreviver. (SOARES, 2004, p. 21) }
\end{aligned}
$$

São inúmeros os desafios a serem superados se quisermos promover um acesso equitativo à leitura. Para Castrillón (2011, p.16), só é possível pensar em democratização da cultura letrada, "quando a leitura constituir uma necessidade sentida por grandes setores da população, e essa população considerar que a leitura pode ser um instrumento para seu benefício e for de seu interesse apropriar-se dela".

Como todo direito, assim também a leitura não deve ser tratada na perspectiva da imposição ou como benesse de alguém ou algum grupo sobre outro, mas conquista construída a partir da tomada de consciência de sua necessidade e importância para o coletivo. Essa consciência (a ser) construída sobre a leitura precisa ser alimentada, pois não se dá de modo espontâneo, mas ocorre num processo formativo reflexivo que dialoga com a realidade.

No entanto, o que se tem verificado são ações pontuais, muito mais paliativas, como campanhas de fomento à leitura, do que propriamente políticas públicas consistentes que promovam o acesso e as oportunidades de formação do leitor.

Castrillón faz uma crítica a tais campanhas, planos e projetos que eventualmente têm sido feitos em todo o mundo, pois mais mascaram o problema do que de fato ajudam a

\footnotetext{
${ }^{6}$ Os dados são do Instituto Nacional de Estudos e Pesquisas Educacionais Anísio Teixeira (Inep) e foram apresentados pelo coordenador-geral dos Programas do Livro do Fundo Nacional de Desenvolvimento da Educação (FNDE), Lauri Cericato, em audiência pública na Câmara dos Deputados (idem).
} 
resolver, uma vez "que acabam por desviar a atenção do verdadeiro problema, criando a ilusão de que se está fazendo algo pela leitura" (CASTRILLÓN, 2011, p. 19).

De acordo com a autora, essas campanhas de caráter mais assistencialistas, desconsideram que a leitura não se tornará necessária sem a "convicção de que ler pode ser um meio para melhorar as condições de vida e as possibilidades de ser, de estar e de atuar no mundo" (CASTRILLÓN, 2011, p. 20). É pertinente compreender que a leitura pode ser uma ferramenta importante no processo de emancipação do sujeito e de construção de uma sociedade mais democrática. No entanto, da mesma forma que a leitura não pode ser divinizada, no sentido de atribuir a ela poderes de salvadora, ela também não pode ser negligenciada, reduzida ao luxo de alguns, associada apenas ao lúdico. Nesse sentido,

Os projetos de leitura precisam [...] demonstrar que a leitura não é um adorno nem
um passatempo e que seu valor não está em oferecer apenas alguns momentos
prazerosos, mas sim que a leitura é um instrumento extremamente útil na
transformação e organização de suas vidas. (CASTRILLÓN, 2011, p. 64)

Essa tomada de consciência de que a leitura pode ter lugar importante na organização da própria vida, poderá ser alcançada no processo formativo vivenciado pelo sujeito.

Diz, ainda, a autora, que o problema "se localiza na educação e nas possibilidades reais de acesso democrático à leitura e à escrita" (CASTRILLÓN, 2011, p. 21). Ela defende que é preciso investir na educação e nas bibliotecas como meios de democratização do acesso à leitura. Trata-se de investir em políticas públicas de educação e cultura, incluindo as bibliotecas, como programas a longo prazo, ao invés das campanhas de sensibilização que não levam a transformações nas instituições (escola e biblioteca).

À escola, precisariam ser dadas as condições para que dê conta da demanda da alfabetização, no sentido pleno, atendendo a todas as categorias, sem privilegiar alguns setores da sociedade; isto é, garantir que todos tenham acesso à cultura letrada. E à biblioteca, deve ser ampliada a quantidade de unidades e aparelhadas para garantir o acesso gratuito às diversas formas de escrita, inclusive às tecnologias.

Muitas vezes os programas e projetos que se intitulam de incentivo à leitura nascem dos interesses do mercado de produção de livros. Na verdade, trata-se mais de incentivo ao consumo dos produtos que são lançados no mercado, do que propriamente de formar leitores.

De acordo com Castrillón (2011, p. 65), "ganharíamos muito se inscrevêssemos os programas de incentivo à leitura e à escrita em projetos políticos de mudança social, de participação, de democratização, para os quais a melhora da educação é uma condição 
básica”. Mais do que produzir ações pontuais, é preciso um projeto político que garanta o acesso equitativo dos cidadãos à totalidade dos bens produzidos pela sociedade. E o acesso à educação, à cultura letrada, à leitura, para além de intervenções efêmeras, quando entendidas como direito, passam a constar como políticas permanentes. Ações de incentivo a leitura, tornam-se projetos que visam proporcionar os meios necessários para desenvolver a formação de leitores, possibilitando a inclusão de todos, inclusive dos professores que deverão tornar-se leitores para poderem formar outros leitores.

Tratando-se do debate em torno das políticas necessárias à garantia do acesso à cultura escrita como um direito cidadão, a autora apresenta algumas conclusões alcançadas em encontros nacionais e regionais que, embora sejam discussões construídas na realidade colombiana, dizem muito ao nosso contexto brasileiro, contribuindo também para a nossa reflexão.

A primeira dessas conclusões trata do "investimento de esforços para melhorar a formação dos docentes" (2011, p. 24), mas uma formação consistente e de longa duração, que considera a prática docente e inclua teoria e reflexão, que forme professores leitores e escritores, "condição primordial para ensinar a ler e escrever" (idem).

Em seguida traz a importância da "escola bem equipada com materiais de leitura [...] que permitam que a escola se converta numa 'comunidade de leitores e escritores"' (LERNER, 2001, apud CASTRILLÓN, 2011, p. 24) e que tenha em seus espaços e tempos, práticas de leitura e escrita equivalentes ao que se utiliza na sociedade e de reflexão e debate para construção do pensamento crítico e criativo.

Outra conclusão que a autora apresenta refere-se à como as bibliotecas públicas devem tornar-se espaços de acesso à cultura letrada para toda a comunidade, não só à população escolarizada (CASTRILLÓN, 2011, p. 25). Para a autora, a universalização do acesso à cultura letrada pressupõe "mudanças de ordem econômica, política e social que garantam maior igualdade na distribuição da riqueza e dos avanços do desenvolvimento" (CASTRILLÓN, 2011, p. 27). Para tanto, é preciso políticas públicas de Estado, elaboradas com a participação da sociedade e que sejam, de fato, coerentes com um processo democrático e de inclusão.

Lembrando Emília Ferreiro, Castrillón (2011, p. 84) ressalta que ler "já não é marca de sabedoria, mas sim de cidadania". Constitui-se elemento importante da democracia, pois não é aceitável uma nação que se diz democrática, manter seu povo não alfabetizado, sem o 
domínio da cultura letrada. É preciso garantir a leitura e a escrita na condição de direitos fundamentais, "como práticas que ajudam as pessoas a construir sua individualidade, a criar seu espaço no mundo e a estabelecer relações com os demais" (CASTRILLÓN, 2011, p. 95). Trata-se do empoderamento do sujeito enquanto cidadão que vai se construindo e conquistando autonomia e emancipação.

Enfim, lembramos com Petit (2008, p.60) que "a verdadeira democratização da leitura é poder ter acesso, se desejarmos, à totalidade da experiência da leitura, em seus diferentes registros”. Entretanto, como alerta Castrillón (2011, p. ?): “Ter acesso à leitura não garante de maneira absoluta a democracia, mas não tê-lo definitivamente a impede ou, pelo menos, a retarda".

\section{A Geladeiroteca na UFMA/Imperatriz}

Para quem trabalha no campo da educação, não é incomum ouvir que os "alunos não leem" ou "não gostam de ler"; ouve-se com certa frequência, nas conversas entre professores, que os estudantes "não cultivam o hábito de ler"; alguns chegam a afirmar que "eles têm preguiça de ler". Tais queixas se referem a estudantes em todas as idades e níveis de ensino.

Zilberman (2008, p. 21), falando sobre o que chamam de crise do ensino da literatura, diz que uma das interpretações dessa afirmação no Brasil, "Numa acepção ampla, significa falta de leitura: recriminam-se os alunos por não gostarem de ler, preferirem outras formas de expressão ou satisfazerem-se com seu estágio de ignorância”. E a responsabilidade com essa situação, hora recai sobre o aluno, hora sobre o/a professor/a, em especial aquele/a que trabalha Língua Portuguesa ou Literatura.

Não é objetivo discutir aqui essa questão, mas parto dela para trazer uma iniciativa de estudantes que se identificam como leitores e desejam proporcionar meios para que outras pessoas também possam ter acesso à fontes diversificadas de leitura, como contraponto a essa percepção, talvez um tanto distorcida do lugar da leitura, sobretudo para os jovens. Pois foi assim que meu caminho se cruzou com a Geladeiroteca, como uma adesão de jovens leitores.

Para falar sobre a criação da Geladeiroteca na UFMA, começo contando um pouco do percurso que fui fazendo; identifico as pessoas que me informaram sobre o projeto, alguns usuários e descrevo as técnicas que utilizei para construir informações.

A forma de abordagem dos informantes ocorreu de modos diferentes. Comecei com Matheus Ian Cidreira Costa, 23 anos, estudante do quinto período do curso de Pedagogia, que 
me foi indicado pelo Valdean, presidente do CAPed, dizendo que esse rapaz era quem lidava com o projeto da Geladeira Literária (é assim que chamam no curso de Pedagogia); até esse momento eu pensava que a iniciativa era do curso de Pedagogia, mas na entrevista, ficou esclarecido que a geladeira:

[...] provavelmente, ela é do curso de Direito; que eles começaram com essa ideia e tudo mais. Só que acabou ficando um pouco parada. Então, como eu não podia mexer, que não era minha, não era do curso de Pedagogia, então eu só tentei arrumar do jeito que tava, eu deixei lá, mas arrumando (Matheus Ian).

Também o Matheus havia se equivocado; ele pensava que a iniciativa tinha partido do curso de Direito. No entanto, olhando e fotografando a geladeira, descobri um texto, resumindo o projeto, que identificava o curso de Ciências Contábeis. Assim, na entrevista com o Matheus é que o estudante ficou sabendo que a ideia da Geladeiroteca surgira no curso de Ciências Contábeis. Essa informação foi importante, pois agora era preciso ouvir quem tinha iniciado o projeto.

Foi então que entrei em contato com uma aluna do curso de Ciências Contábeis que logo afirmou que "essas ideias só poderiam ser da professora Celnia" e explicou que a professora costuma ter ideias diferentes, criativas e que envolvem a turma para além da sala de aula. Estabeleci o contato com a professora, inicialmente por telefone, marcamos entrevista e ela prontamente concordou em falar sobre o projeto.

Conhecendo a história de como se iniciou o projeto, precisava agora ouvir o que pensavam os usuários da Geladeiroteca. Essa não foi uma tarefa fácil, considerando o fato de estarmos já em fins de semestre e os alunos estarem envolvidos com atividades finais. Mas, segui procurando ouvir usuários da Geladeiroteca.

A Maria Carolina, 19 anos, estudante do primeiro período do curso de Pedagogia, já havia me falado, uma ocasião que pegava livros na "geladeira literária". Sua abordagem foi nessa circunstância, em que aproveitei a conversa e perguntei se me concederia uma entrevista em outro momento. Ela concordou.

A abordagem de Sara Lorrana, 18 anos, e Vitor Emanuel, 19 anos, foi aleatória. Eu estava passando na área de convivência, no campus ${ }^{7}$ centro, quando encontrei três estudantes (não nos conhecíamos), perguntei diretamente se eles já tinham ouvido falar da "Geladeira Literária". Responderam que sim e eu perguntei se algum deles já tinha pegado algum livro.

\footnotetext{
${ }^{7}$ Centro de Ciências Sociais, Saúde e Tecnologia.
} 
O rapaz (Vitor) e uma das moças (Sara) disseram que sim. Ambos são estudantes do segundo período do curso de Licenciatura em Ciências Humanas (LCH). Perguntei se poderiam me conceder uma entrevista, explicando que queria escrever um artigo sobre a geladeira e eles concordaram, mas naquele momento estavam indo fazer uma prova; disseram que se eu esperasse, eles retornariam depois que terminassem a atividade. Foi o que fiz: aguardei a ocasião mais propícia para entrevistá-los.

Então, são estes os informantesa: A Professora Celnia, que coordenou a criação do projeto com estudantes de Ciências Contábeis; Matheus, estudante de Pedagogia que se tornou divulgador da Geladeiroteca; Maria Carolina, Sara e Vitor, estudantes que utilizam os livros da geladeira.

Para coletar as informações, utilizei entrevistas semiestruturadas como técnica, "porque esta, ao mesmo tempo que valoriza a presença do investigador, oferece todas as perspectivas possíveis para que o informante alcance a liberdade e a espontaneidade necessárias, enriquecendo a investigação" (TRIVIÑOS, 2006, p. 146).

As entrevistas ocorreram nos meses de junho e julho de 2019, em salas da própria UFMA. Foram gravadas com autorização dos participantes que aceitaram, voluntariamente, colaborar e permitiram que seus nomes fossem divulgados. Depois de transcritas, as entrevistas, procedemos a análise que compõe esta seção do artigo.

\subsection{Como nasceu o projeto}

A ideia da Geladeiroteca não é nova nem pertence originalmente aos estudantes do curso de Pedagogia da UFMA/Imperatriz, como inicialmente supunha. Em uma rápida pesquisa nos sites de busca da internet, podemos localizar diversos projetos dessa natureza. Então qual o diferencial desse aqui? Onde está a sua originalidade? Foi o que tentei descobrir.

O projeto Geladeiroteca, da UFMA/CCSST, nasceu de uma atividade proposta pela professora Celnia Teresinha Bastos de Paula $\operatorname{Costa}^{8}$, quando estava trabalhando a disciplina Filosofia da Ciência no curso de Ciências Contábeis.

De acordo com a professora, desde 2010 tem como prática, em suas turmas, logo no início do semestre, propor aos alunos que promovam alguma ação de intervenção no campo,

\footnotetext{
${ }^{8}$ Psicóloga, professora do Centro de Ciências Sociais, Saúde e Tecnologia (CCSST), campus da UFMA em ImperatrIz-MA.
} 
que pode ser interna ao campus ou externa, como um retorno da Universidade à sociedade. A professora relata:

\begin{abstract}
Então eu sempre trabalhei com as minhas turmas de 2010 pra cá, que todos eles [...] tinham que fazer intervenção em campo. [...] a universidade, ela tinha que sair dentro da sala de aula, e ela tinha que sair dessa fronteira [...] das paredes, né? E ela tinha que fazer alguma coisa na comunidade porque a comunidade tinha que participar [...] a cidade tinha que participar do que que o aluno tava aprendendo dentro do contexto escolar.
\end{abstract}

A ideia era que os estudantes, em grupo ou individualmente, pensassem uma ação que, de algum modo, tivesse uma contribuição social significativa. Eles poderiam escolher entre atuar no próprio campus ou em alguma demanda da cidade. Celnia desafia os alunos no sentido de pensarem e agirem numa perspectiva de construção de uma sociedade melhor. A professora provoca a reflexão e o posicionamento dos estudantes, segundo seu relato:

Olha, cês têm que entender que, [...] de mundo científico, [...] de artigo::... de
livros:.... a gente tem um monte de coisa, já. Agora de sociedade saudável, eu vejo
pouco [...]. Eu não tô nem muito preocupada com titulação de artigo, de nada. Eu tô
preocupada é que vocês comecem a entender que nossa sociedade de alguma forma,
ela vai ter que ser saudável, e nós vamos ter que começar a construir isso, né?. Então
toda turma eu delego, desde o início do semestre, pra eles discutirem entre si e eles
pensarem quê que eles vão fazer de intervenção, ou no campus, ou na cidade... e eu
deixo livre pra eles.

Sobre essa liberdade criativa, é interessante destacar o quanto alguns alunos têm dificuldades de viver essa autonomia sobre suas próprias decisões. Talvez por que estejam imersos numa sociedade e numa escola onde são tutelados na construção do conhecimento, na tomada de decisões sobre si ou mesmo sobre o coletivo. O fato é que, de acordo com a professora Celnia, é comum que haja turmas que manifestam, inclusive, a necessidade que a professora direcione a tarefa e eles apenas cumpram. Conta a professora que "[...] teve grupo já que virou e disse assim pra mim: 'Mas professora, a senhora é que é a professora. A senhora que tem que dizer o que que a gente vai ter que fazer"'. Que educação é essa? Para formar quais sujeitos? Para qual sociedade?

Paulo Freire fala que "O respeito à autonomia e à dignidade de cada um é um imperativo ético e não um favor que podemos ou não conceder uns aos outros" (1996, p. 66). E essa autonomia, que é conquista para o sujeito, só é buscada por aqueles que têm consciência de sua importância e da necessidade.

Retomando a fala da professora Celnia, outra questão que é relevante destacar é a sua perspectiva de sociedade e do papel de cada pessoa na construção desta. O valor atribuído à 
produtividade, exigência da academia, e o que de fato tem importância em sua concepção: "Eu não tô nem muito preocupada com titulação de artigo, de nada. Eu tô preocupada é que vocês comecem a entender que nossa sociedade de alguma forma, ela vai ter que ser saudável, e nós vamos ter que começar a construir isso, né?" Relata a professora sobre seus diálogos com as turmas. E nessa perspectiva de construção de uma sociedade melhor, a professora afirma desafiar os estudantes a realizarem, como uma das atividades valendo nota, alguma “intervenção no mundo". A professora explica que estabeleceu nota para essa ação de modo a garantir que todos participem de alguma ação, em grupo ou individualmente.

Então, numa dessas proposições da professora Celnia a uma turma de Filosofia da Ciência, de Ciências Contábeis, um aluno contou que tinha encontrado uma geladeira abandonada perto da sua casa e já tinha reservado para essa finalidade, caso os colegas concordassem. O estudante tinha feito, também, orçamento da pintura e o grupo dividiu a despesa. De acordo com a professora, "teve um aluno que... ele teve que vender brigadeiro pra conseguir o dinheiro, e não é muito, é porque ele tava muito apertado". Lidar com a precariedade estrutural das instituições públicas, as ausências de condições às vezes mínimas de acesso e permanência de estudantes no ambiente acadêmico, o grande abismo social que separa as pessoas numa mesma sociedade, tudo isso nos leva a pensar o malabarismo que estudantes das camadas populares precisam realizar todos os dias para conseguirem manter-se nos estudos.

A geladeira foi toda pensada por estudantes do $2^{\circ}, 4^{\circ}, 6^{\circ}$ e $10^{\circ}$ período de Ciências Contábeis da UFMA-Centro que cursavam a disciplina com Celnia. Segundo a professora, eles decidiram, entre si, sobre a temática que iriam colocar na arte da geladeira, discutiram as frases que comporiam o visual, planejaram todo o projeto. No final, não era só a geladeira, mas criaram um ambiente no espaço de convivência do campus. Não era só a Geladeiroteca. Colocaram, ainda, "umas estantezinhas do lado [...] uns banquinhos também". Conta, a professora que as estantes e os banquinhos já sumiram, mas ela cobrou providências do prefeito de campus.

Eis a Geladeiroteca pronta. De um lado, a caricatura de Paulo Freire com a citação: "Educação não transforma o mundo. Educação muda as pessoas. Pessoas transformam o mundo." 


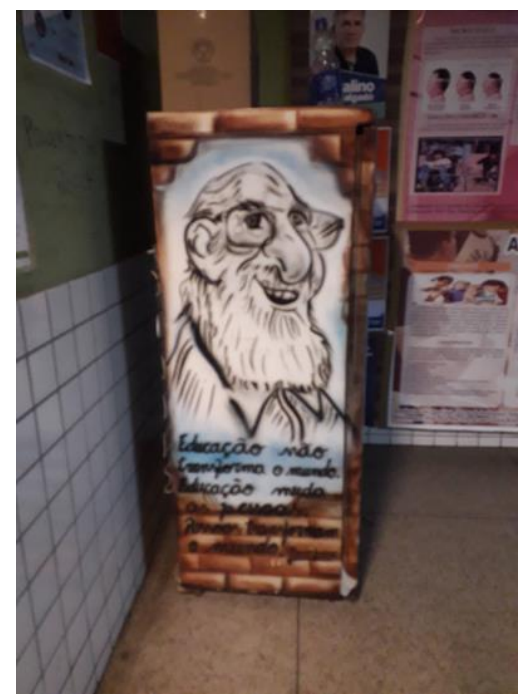

Fonte: Acervo pessoal da pesquisadora/2019.

Na porta da geladeira, a caricatura de José Saramago com a frase: "O conhecimento une cada um consigo mesmo e todos com todos", certamente relevante para os estudantes. Observo o quanto é significativo que a frase sobre conhecimento esteja colocada justamente na porta que pode ser aberta por qualquer pessoa que assim o deseje e onde se encontram livros. Uma interessante representação do que expressam sobre leitura como acesso ao conhecimento.

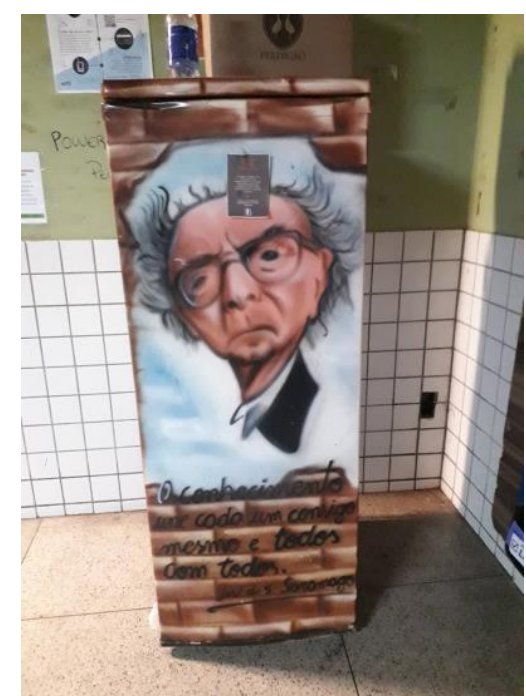

Fonte: Acervo pessoal da pesquisadora/2019.

Na parte interna da porta da Geladeiroteca foi colado um resumo que explica ao leitor, possível usuário, em que consiste o projeto, seus objetivos, orientações de uso da geladeira e como se pode cooperar com o projeto. 


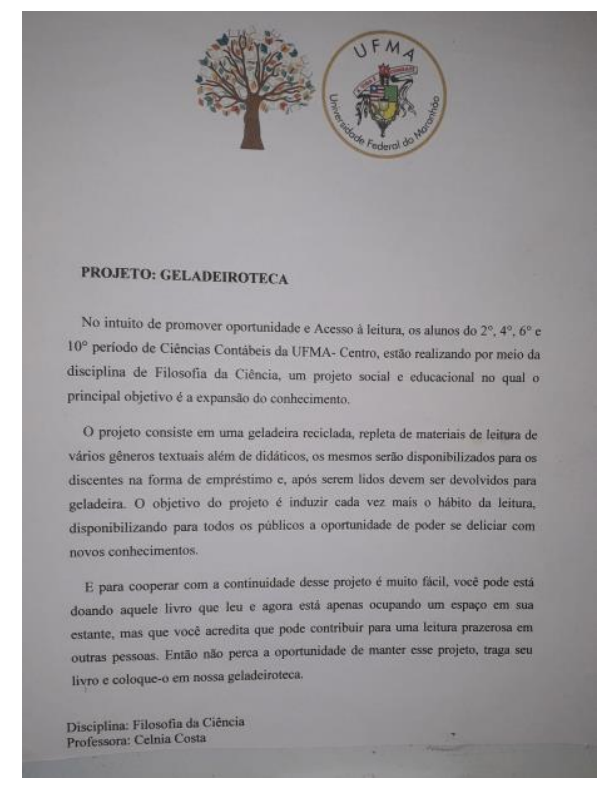

Fonte: Acervo pessoal da pesquisadora/2019.

Os idealizadores da Geladeiroteca da UFMA/CCSST, a identificam como "projeto social e educacional no qual o principal objetivo é a expansão do conhecimento". Acrescentam ainda que pretendem "induzir cada vez mais o hábito da leitura, disponibilizando para todos os públicos a oportunidade de poder se deliciar com novos conhecimentos" (grifo nosso). E, ainda, revelam sua intenção de "promover oportunidade e Acesso à leitura”.

Observam-se várias intencionalidades apresentadas no texto resumo do projeto: expandir conhecimento, induzir o hábito de leitura, promover oportunidade de acesso à leitura. Com isso, podem-se perceber algumas concepções de leitura e leitor presentes nesse discurso.

Ler para ampliar conhecimentos. Revela que os autores do projeto veem a leitura como fonte de aquisição de conhecimentos formais e o leitor, como alguém que traz consigo saberes construídos ao longo de sua história e que, no diálogo com os textos e, eu complementaria, com a realidade e suas vivências enquanto leitor, vai agregando cultura, ampliando seus conhecimentos.

Leitura como hábito a ser induzido. Esta concepção revela uma pretensão de conduzir o sujeito ao hábito da leitura pela oferta de material que gera oportunidade de acesso à leitura. Como hábito, a leitura seria uma prática frequente que, de acordo com o texto do projeto, pode ser induzida com a disponibilização de livros, como se o acesso a livros e outros materiais escritos, por si, já levasse a pessoa ao costume de ler. Este entendimento parece-nos 
um tanto discutível. Primeiro, porque essa ideia de induzir o hábito da leitura desconsidera o processo formativo do leitor que "é levado ao hábito de ler", apenas por ter acesso a materiais escritos. Saber ler não é necessariamente tornar-se leitor.

O hábito de ler não ocorre de modo mágico, rápido, e até prazeroso, como muitos podem pensar, mas é construção e investimento que leva tempo, esforço, dedicação e disciplina; é processo que exige labuta, tomada de consciência do sujeito sobre a sua necessidade de investir na leitura.

No entanto, cabe destacar que, se por um lado, apenas o acesso ao livro sem o necessário investimento na formação do leitor pouco tem contribuído para levar alfabetizados à condição de leitores, por outro lado, a falta de oportunidades de acesso ao livro tampouco ajudará a formar leitores. Talvez a questão maior não seja a tentativa de induzir o leitor, mas criar oportunidades de práticas de leitura significativas, onde o diálogo, a reflexão, o pensamento crítico se façam presentes. Daí a importância da luta por políticas consistentes de democratização da leitura.

Ainda sobre esse objetivo citado no projeto: "induzir cada vez mais o hábito da leitura, disponibilizando para todos os públicos a oportunidade de poder se deliciar com novos conhecimentos", queremos destacar o trecho que fala de "novos conhecimentos", que os estudantes associam sua aquisição a algo prazeroso ("poder se deliciar"). Leitura novamente vista como meio para aquisição de conhecimentos, mas acrescida do qualificativo "novos", deixando claro que são conhecimentos para além do que o leitor já possui. E isso é "prazeroso", adquirir novos conhecimentos, acrescentar ao seu repertório de saberes, novas informações.

Sobre a ideia de leitura prazerosa, pode-se observar presente no texto da Geladeiroteca, além do trecho citado no parágrafo anterior, também quando se refere à doação de livros: "contribuir para uma leitura prazerosa em outras pessoas". Possivelmente se referem à uma leitura que não é obrigatória, que pode ser escolhida pelo leitor a partir dos interesses pessoais, uma leitura mais para "distração", uma leitura lúdica. Mas é interessante notar que o projeto não propõe a doação exclusiva de livros literários que poderiam ser associados à essa "leitura prazerosa". Nessa versão da Geladeiroteca, há o compartilhamento, inclusive de livros didáticos. Pedem doação de "materiais de leitura de vários gêneros textuais além de didáticos". Há uma intenção em oferecer uma diversidade de possibilidades de leitura e uma 
expectativa de que esta interação com a leitura, de algum modo seja algo leve, prazerosa para o leitor.

Outra intenção manifestada no documento é "promover oportunidade e Acesso à leitura". O texto é iniciado por essa frase. Talvez esta seja a verdadeira contribuição do projeto; possibilitar o acesso à leituras diversificadas, talvez até diferentes do que se pode encontrar na biblioteca da universidade, para aquele leitor que já se constitui como tal ou que esteja em processo de desenvolvimento do seu hábito de leitura.

Sobre o acesso aos livros da Geladeiroteca, ocorre em forma de empréstimos e devem ser devolvidos após a leitura. Não há um controle formal dos empréstimos; qualquer pessoa pode pegar e permanecer com os livros o tempo que desejar, como também qualquer pessoa pode deixar livros na geladeira. A manutenção do acervo é realizada pela adesão voluntária, a partir de doações dos próprios usuários. E isto pode ser um problema, pois algumas pessoas apenas descartam o que não querem mais manter em casa, sem um critério mais compatível com a finalidade do projeto.

Vemos aqui algumas diferenças entre o projeto original e o que depois anuncia o estudante Matheus Ian, do curso de Pedagogia que adota a Geladeiroteca, como "Geladeira Literária" e passa a divulgá-la. Mas este já é um dos impactos do projeto que abordo em seguida.

\subsection{Impactos do Projeto Geladeiroteca}

Conforme fui conhecendo a proposta da Geladeiroteca, com as entrevistas concedidas por Matheus e pela Profa. Celnia, logo fui percebendo que, se a ideia da Geladeiroteca nascera em um curso específico - Ciências Contábeis - agora sua abrangência transbordara a fronteira do curso.

Assim, alguns questionamentos começaram a surgir: Como e por que Matheus, aluno do curso de Pedagogia, se envolveu em um projeto do curso de Ciências Contábeis? Quais impactos se podem perceber da ação proporcionada pelo Projeto Geladeiroteca? O que pensam os usuários da Geladeiroteca sobre essa iniciativa? Qual o significado da leitura e da Geladeiroteca para seus usuários?

A história de Matheus Ian se cruza com a Geladeiroteca por causa do gosto pela leitura. Jovem de 23 anos, estudante do quinto período do curso de Pedagogia por ocasião dessa pesquisa, secretário do CAPed e, segundo relata, é também “quem faz essa parte das mídias 
sociais e artes e tudo o mais dos eventos, por exemplo, do simpósio, aquelas artes de divulgação, de produção [...]". Essa informação é importante, porque foi essa experiência com arte e mídias que ele utilizou para divulgar a Geladeiroteca.

Sobre o gosto pela leitura, o jovem revela que vem anterior à escola; sua gênese se encontra no incentivo da mãe. Ao ser questionado sobre o porquê da adesão ao projeto, o quê o moveu à ação, Matheus responde:

\begin{abstract}
Primeiro porque eu gosto muito de ler. Eu comecei a ler porque minha mãe comprava livros pra mim naquelas revistas da Avon que tinha muito. Ela comprava e me dava pra mim ler e eu comecei a gostar bastante. Antes eu não gostava, achava muito cansativo. Mas depois eu comecei a ler [...].
\end{abstract}

Certamente a postura da mãe que foi criando oportunidades do filho ter sempre livros a seu alcance, muito contribuiu para que Matheus fosse se construindo leitor. Talvez por isso, também, tenha despertado essa preocupação em compartilhar o que para ele era tão importante. Ele queria disponibilizar para outras pessoas os livros que tinha lido, e gostado de ler; como se pudesse proporcionar aos outros aquela experiência que para ele era significativa: “[...] por que não a gente pegar aquele livro que tá guardado e que a gente sabe que é bacana e que outras pessoas podem gostar e entregar?” Essa foi a motivação inicial do Matheus.

Pode-se dizer que os criadores e mantenedores da Geladeiroteca, em certa medida, são como mediadores de leitura, uma vez que buscaram, com o projeto, aproximar livros de leitores em potencial. Segundo Yolanda Reyes" (2019), “Os mediadores de leitura são aquelas pessoas que estendem pontes entre os livros e os leitores, ou seja, que criam as condições para fazer com que seja possível que um livro e um leitor se encontrem”. Vejo o projeto e a iniciativa de Matheus como essa ponte que liga leitor e livro. Foi isso que, em última instância, se procurou fazer com a Geladeiroteca; possibilitar que as pessoas tivessem contato com os livros e, com isso, buscassem a leitura como algo "que se deliciassem", no dizer dos criadores do projeto.

Os usuários da Geladeiroteca são possíveis leitores que buscam, voluntariamente, fontes de leitura livres das exigências da leitura obrigatória da academia, da escola; podem usar critérios subjetivos para escolher o que ler. Enquanto que os doadores de livros atuam, de certa forma, como mediadores, pois selecionam o que oferecer aos leitores; embora não

\footnotetext{
${ }^{9}$ Disponível em Glossário CEALE. Termos de Alfabetização, Leitura e Escrita para educadores. <http://ceale.fae.ufmg.br/app/webroot/glossarioceale/verbetes/mediadores-de-leitura> Acesso em 07/08/2019.
} 
estejam ao lado do leitor na ocasião da leitura, mas criam condições para que o leitor se aproxime dos livros e possa fazer uso, escolhendo livremente o que ler. Para Reyes (2019),

A experiência de encontrar os livros certos nos momentos certos da vida, esses livros que nos fascinam e que nos vão transformando em leitores paulatinamente, não tem uma rota única nem uma metodologia específica; por isto os mediadores de leitura não são fáceis de definir (idem). (REYES, 2019)

A Geladeiroteca foi um modo criativo que os estudantes encontraram de tentar promover o acesso a livros ou pelo menos de compartilhar livros com a expectativa de contribuir com alguma ação de incentivo à leitura. Claro que nem sempre é assim, observamos que às vezes o doador de livros quer, apenas, ver-se livre de algum material que não lhe tem mais serventia em casa.

Com Matheus, houve um misto de intenções: tinha o interesse em descartar livros usados, mas aqueles livros que para ele tinham grande valor, que considerava interessantes, ele desejava que chegassem a outras pessoas: "No primeiro momento, eu só... pra ser sincero eu tava [...] tirando livros que eu tinha, de dentro de casa, pra dar pra outras pessoas", relata. E na busca de fazer com que seus livros alcançassem novos leitores, o jovem foi surpreendido. Ele conta que começou pensando diferentes estratégias de doação dos seus livros.

Então todos aqueles livros eu já tinha lido umas duas, três vezes. Aí eu pensei: Por que não entregar pra outras pessoas lerem? [...] eu pensei em [...] só botar num canto qualquer da UFMA sabe [...] Deixar lá pra pessoa pegar. [...] depois eu pensei em colocar uma mesa com um nomezinho lá e tudo bem.

Foi então, que aconteceu o encontro de Matheus e a Geladeiroteca:

Aí eu vi a geladeira. Aí eu falei: por que não botar na geladeira, se já tem a geladeira aqui? Aí, foi ai que fui olhar a geladeira, como ela tava. Ela tava muito bagunçada, muito suja. Aí eu limpei, arrumei. Eu não tirei as coisas que tavam lá porque... não cabia a mim tirar. Então, a parte de cima da geladeira, eu limpei toda ela, e coloquei os livros que eu tava doando lá.

Uma atitude que parecia ter se encerrado na doação, terminou tendo outro impacto para o rapaz, pois o que ocorreu em seguida o surpreendeu: "E foi engraçado que, quando eu coloquei, eu saí e fui pro Centro Acadêmico. E depois quando eu voltei, acho que uns dez minutos, não tinha mais nenhum livro. Eu fiquei muito surpreso, muito mesmo. Porque eu levei um monte..." Sobre os livros doados, Matheus contava com um pequeno acervo de literatura de massa, na linha dos best-sellers. 
Eu trouxe os livros de Harry Potter, trouxe também Crepúsculo, trouxe O menino do pijama listrado e trouxe uma coleção do John Green que é: Cidade de Papel, A culpa é das estrelas, esses livros assim.

[...] eu também tinha um que era A vontade de ser invisível, que é muito, muito bom.

Com a doação desses livros aconteceu o primeiro contato de Matheus com a Geladeiroteca. E já se percebem as primeiras diferenças do projeto original, que Matheus não percebeu colado na parte interna da porta da geladeira. Enquanto o pessoal de Ciências Contábeis informava que os livros “[...] serão disponibilizados para os discentes na forma de empréstimo e, após serem lidos devem ser devolvidos para geladeira", Matheus fazia o contrário; não se tratava de empréstimo, para ele, mas de doação com o compromisso de fazer circular cada obra. "E... eu deixei lá [...] Claro que eu deixava com um recadinho avisando: 'Olha, passe adiante, tá? Não precisa deixar na geladeira de novo. É só passar adiante'". Segundo o jovem, ele anotara o recadinho em cada livro doado.

A rapidez com que as pessoas foram pegando os livros teria sido para Matheus um momento impactante que provocou uma reflexão no estudante a partir da sua experiência de doador de livros.

\begin{abstract}
Mas eu vi que o pessoal tava curtindo, então comecei a pensar melhor no que aquilo significava. Significa que as pessoas gostam de ler. Elas precisam apenas de ter o que ler. Então, foi aí que eu comecei a pensar: isso realmente vale a pena. Vale a pena é... investir em pessoas que gostam de ler, que querem livros, e por que não a gente pegar aquele livro que tá guardado e que a gente sabe que é bacana e que outras pessoas podem gostar e entregar? Aí foi assim que foi surgindo.
\end{abstract}

Matheus vai ampliando sua percepção em relação ao interesse das pessoas pela leitura. Descobriu que não é possível fazer afirmações generalizadas, como muitas vezes se ouve, que as pessoas não gostam de ler. A questão talvez seja que possibilidades de leitura essas pessoas tiveram acesso?

O que observa ao deixar livros na geladeira, a leitura que faz das atitudes daqueles que vão em busca dos livros, despertam no jovem Matheus uma atitude não mais de apenas deixar livros por deixar, mas doar livros para que outras pessoas tenham a oportunidade de ler aqueles livros que ele considerava muito bons. Ele passou de doador a divulgador da geladeira. Conta Matheus:

A galera começou pegar. Então eu comecei, eu percebi que o pessoal tava pegando, tava curtindo. Então, pra poder divulgar, eu fiz uma arte: "Doe livros para a Geladeira Literária da UFMA”. Só que eu deixava uma observação: Não são livros didáticos, não são revistas, são livros, como eu posso dizer...? Infanto-juvenil, alguma coisa assim... 


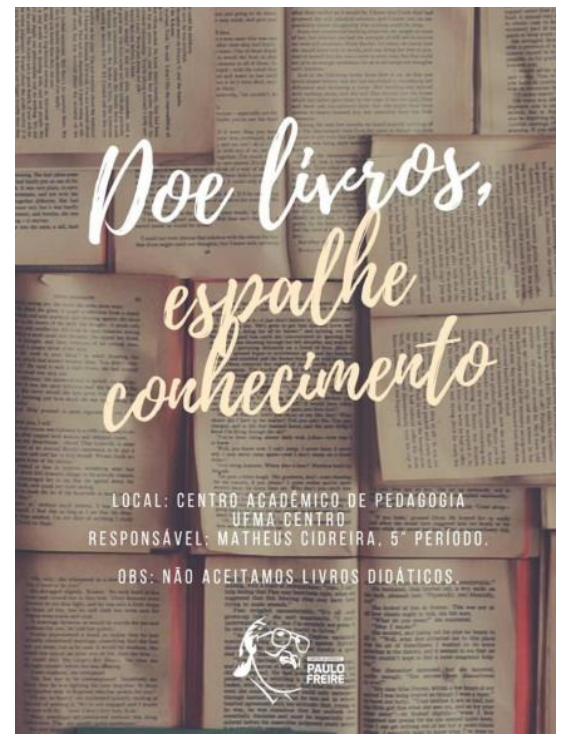

Fonte: Arquivo pessoal de Matheus Ian/2019.

Novamente uma distinção entre o projeto original e a intervenção de Matheus. O texto do projeto informava: "O projeto consiste em uma geladeira reciclada, repleta de materiais de leitura de vários gêneros textuais além de didáticos" (grifo nosso). Enquanto o projeto incluía, claramente, os livros didáticos, Matheus afirma que estes eram pouco procurados e, por isso, na "sua campanha" de doação de livros, a prioridade eram os literários; "não aceitamos livros didáticos" (grifo nosso), deixa claro no material de divulgação. E na entrevista confirma: "Não são livros didáticos, não são revistas, são livros, como eu posso dizer...? Infanto-juvenil, alguma coisa assim... (grifo nosso),” O projeto original vai tomando outros contornos, ao sair do "controle" dos seus idealizadores. Mesmo Matheus não se sentindo no direito de retirar materiais que estavam ali dentro, uma vez que sabia que não era do seu curso, ele toma para si a responsabilidade da divulgação e a faz de acordo com o que considera mais adequado, incentivando doações de materiais que, na sua avaliação, seriam mais procurados.

Além de pontuarmos essas diferenças, entre o projeto original e as ideias de Matheus, outro aspecto nos chama atenção nessa fala do estudante; a dificuldade em nomear o estilo de livros quando se trata de literatura: “[...] são livros, como eu posso dizer...? Infanto-juvenil, alguma coisa assim..." (grifo nosso). Possivelmente, por uma frágil formação literária, o jovem tem dificuldades para identificar o tipo de produção literária que se referia. Apoia-se numa classificação que em geral se vê nos catálogos das editoras e que se torna corrente nas falas das escolas. 
Essa mesma dificuldade pode ser percebida nas falas de outros alunos entrevistados, como é o caso de Maria Carolina, aluna do primeiro período do curso de Pedagogia, que também aparenta hesitação ao tentar identificar os tipos de livros escolhidos: "Eu já peguei alguns, meio... alfabetização, peguei alguns infanto-juvenil..." (grifo nosso). Parece resgatar, como apoio, a mesma lógica de conceito que Matheus utiliza.

O mesmo se repete com Vitor Emanuel e Sara Lorrana, alunos do segundo período do curso de Licenciatura em Ciências Humanas (LCH). Quando falavam sobre que tipo de livros pegaram na Geladeiroteca, Vitor conta que: "Um foi mais ou menos literatura mesmo e o outro foi alguma coisa relacionado a.... como se portar em entrevista de emprego, na sociedade..." e Sara explica: "Eu peguei sobre tudo, sobre capacitação de professores até livros, livros normais mesmo que contam histórias fictícias" (grifo nosso). Vitor parece não estar tão certo sobre o que seria mesmo literatura, mas utiliza a palavra para nomear um tipo especifico de leitura. Sara não consegue nomear o tipo de livro, mas o identifica com uma característica em que é possível entender que se trata de literatura.

Referindo-se aos livros literários, Matheus, assim como os outros estudantes, parecem que "reproduzem conceitos de leitura e de literatura pertencentes ao 'senso comum' da comunidade interpretativa de que fazem parte" (PINHEIRO, 2004, p.117), demonstrando ainda pouco conhecimento do que realmente seja literatura.

Mas, o fato é que a divulgação foi feita pelas redes sociais do CAPed e por meio de panfletos colados pelo campus. O resultado foi profícuo tanto em relação à doações como para quem queria ler. Matheus destaca um episódio inusitado ocorrido durante uma doação.

E teve um momento até engraçado que uma amiga minha, de Pedagogia também,
me trouxe vários livros; umas coleções. E eu acabei deixando lá e uma menina do
Direito viu e ela ficou apaixonada pela minha atitude de deixar livros lá e ela disse
que era muito bacana ver que as pessoas estavam fazendo isso, me pediu até um
abraço.

As reações de fato foram diversas; nem sempre tão efusivas como a relatada, mas as informações começaram a alcançar certo público.

Maria Carolina conta que soube da geladeira pelo Instagram do CAPed, confirmando a iniciativa de Matheus: "Então, da geladeira eu fiquei sabendo pelo Instagram. Que eles tem uma página no Instagram e eles sempre colocam os livros. Quando vão chegando livros novos eles sempre colocam e quem tem interesse vai atrás". 
Sara Lorrana também teve acesso à informação pelas redes sociais: "Eu fiquei sabendo através de algumas publicações na internet de alguns amigos que estavam colocando livros. E ai eu fui até ela buscar alguns deles".

E Vitor Emanuel ficou sabendo por sua amiga Sara Lorrana: "Ela já costumava pegar livros, aí ela me chamou. Eu vi o projeto, achei interessante e comecei participar... colhendo livros".

Sobre o que estes jovens pensam acerca da ideia da Geladeiroteca, são unânimes em destacar sua relevância sobretudo por poderem ter acesso a diferentes tipos livros, em especial aos literários.

Para Maria Carolina, a inciativa desse projeto tem particular importância para aqueles e aquelas que gostam de ler, mas não têm acesso aos livros por sua condição socioeconômica. Diz a estudante sobre o projeto:

Muito bom porque pra quem é de baixa renda, é uma ajuda muito grande, porque os livros são bastante caros, ultimamente. Então incentiva muito a leitura, porque não é fácil é... comprar, ultimamente. Então, isso é uma ótima iniciativa... deles, porque incentiva muito... o gosto pela leitura.

Sobre essa dificuldade de aquisição de livros, Soares (2004, p.23) destaca que "Este é um país de livros caros para uma população em sua maioria pobre. [...] cresce a indústria do livro, sem que a isso corresponda um crescimento das condições de possibilidade de consumo do livro", confirmando o que a estudante afirma.

A entrevistada revela, ainda que gosta muito de ler e que costuma utilizar as tecnologias disponíveis a seu acesso para selecionar suas leituras. "Leio muito pelo celular, PDF, e agora, com a geladeira, eu pego algumas coisas". Interessante é que, apesar do seu acesso ao celular e à internet, a leitora, ainda prefere o livro impresso: “[...] sim, uso o celular. Tem uns sites que disponibilizam livros em PDF. Eu baixo sempre, eu tenho bastante. A geladeira veio pra (risos) adicionar a ele." Completa que no primeiro semestre letivo de 2019 já pegou uns três livros.

Sara justifica porque gostou do projeto, enfatizando dificuldades de acesso a livros que, por motivos financeiros ou outros motivos o leitor não consegue:

$\mathrm{Eu}$ gostei do projeto. Eu achei o projeto bastante interessante, justamente pela questão, tipo, algumas pessoas não conseguem encontrar alguns livros ou elas não têm até dinheiro pra comprar eles e vem outras pessoas que têm e colocam por lá e fica até facilitado a transferência de conhecimento. 
Vitor destaca a importância do acesso aos livros, chamando atenção para o uso da biblioteca que, segundo ele, é burocrático, o que desestimula sua frequência:

Eu acho que iniciativas como essa devem ser cada vez mais comuns, né? Porque nem todo mundo tem acesso à lei... à livros. Pegar livro na biblioteca acaba tendo uma burocracia que acaba desanimando, desestimulando, então, eu acho que fica mais fácil, iniciativas como essa.

O apelo à democratização da leitura parece ser pertinente às falas dos três jovens. Maria Carolina e Sara falam da questão econômica, enfatizada no alto custo dos livros, que restringe os tipos de leitores que podem ter acesso ao livro como bem de consumo, menos ainda enquanto direito de todos. Vitor critica o acesso dificultado nas bibliotecas por causa de mecanismos burocratizantes que, segundo ele, desestimulam o leitor a fazer uso do acervo das bibliotecas.

É significativo o que dizem esses estudantes sobre a leitura para eles. Maria Carolina afirma:

\begin{abstract}
Então, eu considero a leitura como de fundamental importância na minha vida, porque além de ser um prazer, que eu conheço diversas histórias, conheço o pensamento de outras pessoas, conheço as coisas novas. [...] ela me contribui muito pra minha escrita, pro meu vocabulário... aumenta, né? Minha escrita melhora bastante a partir da leitura. Então, eu... a leitura é de fundamental importância pra mim. Representa muito. Eu conheço o desconhecido através da leitura.
\end{abstract}

A estudante atribui à leitura várias contribuições em sua vida. Refere-se à leitura como experiência lúdica (prazer), talvez por ter ouvido esse discurso em campanhas de incentivo à leitura na mídia ou mesmo na educação básica; traz também elementos de cunho pedagógico, ao referir-se ao uso da leitura como meio para melhorar a escrita, ampliar vocabulário. Mas também é possível observar outras possibilidades que a leitura proporciona e que ela percebe, ampliando o universo da leitura de livros literários (“[...] conheço diversas histórias”) para outros formatos de leitura que geram outros tipos de conhecimentos (“[...] conheço o pensamento de outras pessoas, conheço as coisas novas”) que poderíamos dizer como filosóficos e científicos ("Eu conheço o desconhecido através da leitura”).

Quanto à Sara, declara a leitura como fonte de lazer, mas também como inspiradora que alimentaria os diálogos a partir de conhecimentos obtidos. Diz Sara Lorrana:

Eu uso ela tanto pelo lazer como também como forma de adquirir mais conhecimento. Porque como eu estou num curso de licenciatura, eu gosto de conversar com as pessoas, eu gosto de ter certo conhecimento pra falar com ela, por exemplo, sobre, sobre algumas histórias fictícias ou até assunto que li em algum livro, tipo, de transferir o conhecimento pra pessoa, de ensinar ela uma... como ensinar uma tarefa ou outra coisa. 
Sara, assim como Maria Carolina, também enfatiza a leitura, em princípio, como lazer, como atividade que não requer maiores esforços e comprometimento; percebe-se a reprodução do discurso da leitura como ato prazeroso, tão presente nos projetos de leitura das escolas, nas mídias, no mercado editorial de livros, sobretudo literários. No entanto, ela acrescenta outras contribuições interessantes da leitura na sua vida, como a aquisição de conhecimentos, garantindo-lhe um repertório de saberes que favorece o diálogo com outras pessoas. E esse repertório vai desde o conhecimento literário (“[...] eu gosto de ter certo conhecimento pra falar [...] sobre algumas histórias fictícias") até outros saberes que possam ser transmitidos a alguém ("[...] assunto que li em algum livro, tipo, de transferir o conhecimento pra pessoa, de ensinar ela uma... como ensinar uma tarefa ou outra coisa").

Para Vitor, a prática de leitura está ligada à superação da ignorância. Tem a ver com situar-se na sociedade, ter um lugar legitimado, conquistado pelo conhecimento socialmente reconhecido. De certo modo, Sara também busca esse lugar social, ao buscar, na leitura, ampliar seu universo temático para interagir com as pessoas. No caso de Vitor, ele declara:

Eu acho que a leitura contribui no sentido de que quanto mais nós lemos, mais nós adquirimos conhecimentos e não passamos como ignorantes na sociedade. De certa forma, aos iletrados. Então, eu acho que nesse sentido, tá buscando ler é buscar ao mesmo tempo conhecimento. E conhecimento, hoje em dia, é essencial.

O jovem completa a fala fazendo uma afirmação contundente, mas também reveladora do discurso dos tempos atuais, da chamada sociedade da informação, do conhecimento ("E conhecimento, hoje em dia, é essencial"). Conhecimento válido, para ele, é o que se encontra nos livros.

Sobre gostar ou não de ler, o prazer de ler, para Vitor, não é a questão central, o que talvez diferencie um pouco das concepções de leitura de Sara e, sobretudo de Maria Carolina. Para o estudante, não se trata de ser uma atividade prazerosa, de lazer, o estudante a identifica como prática necessária. Ao ser questionado sobre gostar de ler, ele respondeu: "Meu curso me obriga, mas eu já gostava". Embora afirme gostar de ler, entende que esta é uma exigência da área que escolheu (LCH) e da sociedade em que está inserido, pois pela leitura ele acessa conhecimentos e, de posse destes, poderá participar, de modo mais ativo, da vida política, social e econômica, isto é, exercer cidadania. E Castrillón (2011, p. 62) nos alerta que: “Ter acesso à leitura não garante de maneira absoluta a democracia, mas não tê-lo definitivamente a impede ou, pelo menos, a retarda". 
Assim a leitura pode ter uma função social importante que é de empoderamento do leitor que vai construindo seu próprio discurso ou como diz Petit (2008, p. 37): “[...] mesmo que a leitura não faça de nós escritores, ela pode, por um mecanismo parecido, nos tornar mais aptos a enunciar nossas próprias palavras, nosso próprio texto, e a ser mais autores de nossas vidas", portanto sujeitos emancipados, construtores da própria história.

\section{Considerações finais}

É fato que, para a maioria dos jovens brasileiros, a escola é o principal (ou o único) lugar de acesso à leitura literária. No entanto, são os textos didáticos e/ou acadêmicos, os principais textos que têm oportunidade de ler durante seu percurso na educação básica e até mesmo na universidade, para aqueles que conseguem chegar ao ensino superior.

Constatamos também que cada pessoa é um leitor, antes mesmo de sua formação escolar, mas é preciso que o ambiente formativo as ajude perceber que suas vivências com a escrita, com o texto, acontecem mesmo antes da sua educação formal, fazendo parte do seu cotidiano. As experiências de leitura vivenciadas pelo estudante em outros lugares e momentos muitas vezes são desconsideradas.

Nesse artigo procuramos refletir sobre democratização da leitura, a partir do Projeto Geladeiroteca na UFMA, campus centro, em Imperatriz-MA, em diálogo com alguns autores, como Castrillón, Freire, Petit, Rouxel, Soares, Zilberman, entre outros

Defendemos a leitura entendida como uma experiência pessoal do leitor com o texto, que propicia a construção da sua individualidade, do seu espaço no mundo, como diz Castrillón, e das suas inter-relações.

Como direito de todos, a leitura não pode ser imposta, mas é conquista construída a partir da tomada de consciência de sua necessidade e importância para a formação do cidadão e a construção da sociedade. Não pode nem deve ser manipulada como instrumento de poder, de dominação, mas como ato que propicia a conquista de autonomia do pensamento, da consciência crítica, da própria condição de sujeito de direito, de cidadão, dificultando o poder de dominação, de controle. Trata-se do empoderamento do sujeito enquanto cidadão.

Nesse sentido não basta saber ler, no sentido da ação formal de decodificar a escrita, é preciso tornar-se leitor, como alguém capaz de dialogar com o texto, com o mundo, com a realidade para, a partir dela e com ela, buscar alternativas de transformação. 
Assim, é que consideramos que apenas uma legislação que garanta o direito ao acesso a um ambiente com livros, não significa democratização das condições essenciais para garantir a leitura. A precariedade de espaços, livros e outros equipamentos, a falta de formação de mediadores de leitura são alguns dos obstáculos ao processo de democratização da leitura.

Para os estudantes que pensaram a Brinquedoteca, assim como os que a utilizaram, essa iniciativa foi relevante, pois eles vivenciam a grande lacuna no acesso a livros em nossa realidade, seja pela questão econômica, pelos altos preços para uma parcela da população que tem baixa renda, seja pela limitação de acesso à diversidade de obras ou ainda pela burocratização existente nas bibliotecas que dificultam o seu uso. Tais obstáculos contribuem para restringir os tipos de leitores que podem ter acesso ao livro como bem de consumo, ou como direito.

Embora compreendamos que ações pontuais, como essa da Geladeiroteca, não resolvam a questão da leitura de modo mais efetivo, mas elas revelam o interesse que há sobre a leitura. Como constata Matheus, "significa que as pessoas gostam de ler. Elas precisam apenas de ter o que ler".

De acordo com os entrevistados, eles buscam nas leituras diferentes finalidades; ler para adquirir e ampliar conhecimentos, leitura como experiência lúdica, ou ainda, de cunho pedagógico, leitura como meio para melhorar a escrita, ampliar vocabulário.

Alguns também procuram ampliar o universo da leitura de livros literários para outros formatos de leitura que geram outros tipos de conhecimentos que poderíamos chamar de filosóficos e científicos. Além disso, citaram a leitura como inspiradora de diálogos, uma vez que propicia um repertório de saberes que favorece a comunicação com outras pessoas.

Essa busca, na leitura, de ampliação do seu universo temático para interagir com as pessoas, tem a ver com situar-se na sociedade, ter um lugar legitimado, conquistado pelo conhecimento socialmente reconhecido.

Vitor inclusive afirma que, para ele, a prática da leitura está ligada à superação da ignorância e a identifica como prática necessária, uma vez que o "conhecimento, hoje em dia, é essencial".

A Geladeiroteca foi, então, uma maneira criativa que os estudantes encontraram de compartilhar livros com a intenção de contribuir com uma ação que aproxima livro do leitor, incentivando à leitura. 
Enfim, no atual contexto em que se insere o Brasil, a prática da leitura pode ser promovida como ato de resistência às politicas de desmonte dos direitos básicos da população, como a educação, por exemplo. Ler, torna-se, então, importante sinal de cidadania, na luta pela democracia.

\section{Referências}

CASTRILlÓN, Silvia. O direito de ler e de escrever. Tradução: Marcos Bagno. São Paulo: Editora Pulo do Gato, 2011.

FREIRE, Paulo. A importância do ato de ler: em três artigos que se completam. 23 ed. São Paulo: Autores Associados: Cortez, 1989.

FREIRE, Paulo. Pedagogia da autonomia: saberes necessários à prática educativa. 9 ed. São Paulo: Paz e Terra, 1996.

FREIRE, Paulo. Educação como prática da liberdade. 17 ed. Rio de Janeiro: Paz e Terra, 1986.

MARTINS, Aracy e VERSIANI, Zélia. Um jogo que vale a pena: democratizar a leitura literária. In: SANTOS, Maria Aparecida Paiva Soares dos [et al.]. (org.). Democratizando a leitura: pesquisas e práticas. Belo Horizonte: Ceale; Autêntica, 2004. p. 9-16.

PETIT, Michèle. Os jovens e a leitura: uma nova perspectiva. Tradução: Celina Olga de Souza. São Paulo: Ed. 34, 2008.

PINHEIRO, Marta Passos. Reflexões sobre práticas de letramento literário de jovens: o que é permitido ao jovem ler? In: SANTOS, Maria Aparecida Paiva Soares dos [et al.]. (org.). Democratizando a leitura: pesquisas e práticas. Belo Horizonte: Ceale; Autêntica, 2004, p.111-120.

ROUXEL, Annie. Práticas de leitura: quais rumos para favorecer a expressão do sujeito leitor? Tradução: Neide Luzia de Rezende e Gabriela Rodella de Oliveira. Cadernos de Pesquisa, v.42 n.145 p.272-283 jan./abr. 2012.

REYES, Yolanda. Mediadores de leitura. Tradução: Elizabeth Guzzo de Almeida. FaE/UFMG. Disponível em Glossário CEALE. Termos de Alfabetização, Leitura e Escrita para educadores. 〈http://ceale.fae.ufmg.br/app/webroot/glossarioceale/verbetes/mediadoresde-leitura $>$ Acesso em 07/08/2019.

SILVA, Ezequiel Theodoro da. Literatura e Pedagogia: Interpretação Dirigida a um Questionamento. In: ZILBERMAN, Regina. SILVA, Ezequiel Theodoro da. Literatura e pedagogia. 2 ed. São Paulo: Global; Campinas: ALB-Associação de Leitura do Brasil, 2008, p. 39-48. 
SILVA, Ezequiel Theodoro da. Descomplicando o Ensino de Literatura. In: ZILBERMAN, Regina. SILVA, Ezequiel Theodoro da. Literatura e pedagogia. 2 ed. São Paulo: Global; Campinas: ALB-Associação de Leitura do Brasil, 2008. p. 55-61.

SOARES, Magda. Leitura e democracia cultural. In: SANTOS, Maria Aparecida Paiva Soares dos [et al.]. (org.). Democratizando a leitura: pesquisas e práticas. Belo Horizonte: Ceale; Autêntica, 2004. p.17-32.

ZILBERMAN, Regina. Sim, a Literatura Educa. In: ZILBERMAN, Regina. SILVA, Ezequiel Theodoro da Silva. Literatura e pedagogia. 2 ed. São Paulo: Global; Campinas: ALBAssociação de Leitura do Brasil, 2008. p. 17-24.

ZILBERMAN, Regina. Respondendo em Forma de Proposta. In: ZILBERMAN, Regina. SILVA, Ezequiel Theodoro da Silva. Literatura e pedagogia. 2 ed. São Paulo: Global; Campinas: ALB-Associação de Leitura do Brasil, 2008. p. 51-54.

Recebido em 23 de setembro de 2019. Aceito em 14 de novembro de 2019. 